\title{
Amelioration of Acidic Nitisols Using Lime and Vermicompost in Negasa Area, East Wollega Zone, Ethiopia
}

Temesgen Chimdessa

Oromia Agricultural Research Institute (OARI), Nekemte Soil Research Center, Nekemte, Ethiopia

Email address:

temesgenchimdessa468@gmail.com

\section{To cite this article:}

Temesgen Chimdessa. Amelioration of Acidic Nitisols Using Lime and Vermicompost in Negasa Area, East Wollega Zone, Ethiopia. International Journal of Energy and Environmental Science. Vol. 6, No. 1, 2021, pp. 1-10. doi: 10.11648/j.ijees.20210601.11

Received: December 28, 2020; Accepted: January 14, 2021; Published: January 28, 2021

\begin{abstract}
The study was conducted at Negasa area in Guto Gida district to mitigate soil acidity using lime and vermicompost application on bread wheat land use of farmer's field during 2018 main cropping season. The factors studied were four levels of agricultural lime $(0,50,100$ and 150\% RR rated based on exchangeable acidity method) applied one month before planting and three levels of vermicompost $\left(0,2.5\right.$ and $\left.5 \mathrm{t} \mathrm{ha}^{-1}\right)$ applied two weeks before planting. The treatments were laid out as a RCBD in a factorial arrangement, and replicated three times. Representative soil samples were taken before and after planting. The soil physicochemical properties were analyzed following standard procedures. The soil $\mathrm{pH}$ and exchangeable basic cations ( $\mathrm{Ca}$ and $\mathrm{K}$ ) were significantly increased by $7.62,31.16$ and $26.08 \%$ respectively while exchangeable acidity and exchangeable $\mathrm{Mg}$ were significantly decreased by 47.73 and $26.53 \%$ respectively due to lime application at a level of $150 \% \mathrm{RR}$ compared to control. While only exchangeable $\mathrm{Mg}, \mathrm{K}$ and Na and soil bulk density were improved due to vermicompost application. The interaction effect of lime and vermicompost significantly influenced bulk density and total nitrogen of the soil. Simple correlation analysis among soil properties indicates that soil exchangeable acidity is significantly and negatively correlated with soil $\mathrm{pH}$, exchangeable $\mathrm{Ca}$ and $\mathrm{Na}$. It can be concluded that application of lime at the rate of $150 \%$ RR improve most chemical properties of acidic soil. Similar effort should be done over years to determine the long-term effect of lime and vermicompost on such acidic soil properties.
\end{abstract}

Keywords: Lime, Recommended Rate, Vermicompost

\section{Introduction}

Acidity-related soil fertility problems are the main factor that limit and prevent profitable and sustained soil productivity in many parts of the world [24]. Approximately $50 \%$ of the worlds' arable soils are acidic and may be subjected to the effect of aluminum (Al) toxicity particularly in the tropics and subtropics which account for $60 \%$ of the acid soils in the world [34]. From the total area of Ethiopian land (111.8 million hectare), about $40.9 \%$ of area is covered by strongly to weakly acidic soils. In the western part of the country such as Assosa, soil acidity is a well-known problem limiting crop productivity [21]. Most cultivated lands of the Ethiopian highlands are prone to soil acidity due to removal of ample amount of nutrients by leaching, crop mining and runoff.

Soil acidity affects the growth of crops because acidic soils contain aluminum and manganese at toxic levels. Acidic soils are also characterized by deficiency of essential plant nutrients such as $\mathrm{P}, \mathrm{N}, \mathrm{K}, \mathrm{Ca}, \mathrm{Mg}$, and Mo [33]. In acid soils, excess aluminum primarily injures the root apex and inhibits root elongation [50]. The poor root growth leads to reduced water and nutrient uptake, and consequently crops grown on acid soils are confronted with poor nutrients and water availability. The net effect of which is reduced growth and yield of crops [24]. The most common and widely used method to overcome soil fertility problem due to acidity is liming (13). Its direct effect is soil $\mathrm{pH}$ increase [11]. Lime reduces $\mathrm{Al}, \mathrm{H}, \mathrm{Mn}$, and $\mathrm{Fe}$ toxicities and increases $\mathrm{P}, \mathrm{Mg}, \mathrm{Ca}$ and Mo availability in acidic soils [36, 32, 42].

Liming increased plant $\mathrm{P}$ uptake by decreasing $\mathrm{Al}$ impacts in soils with high exchangeable and soluble $\mathrm{Al}$ [10]. Application of organic materials to acidic soils has also been proved to be an efficient alternative to the use of lime [45]. Organic fertilizer has been recognized as an effective means for improving soil aggregation, structure and fertility, 
increasing microbial diversity and populations, improving the moisture-holding capacity of soils and increasing the soil cation exchange capacity (CEC). The use of organic amendments such as traditional thermophilic composts has been recognized as an effective means for improving soil physicochemical properties and crop yields [43].

Maheswarappa et al. (1999) reported as increased soil organic carbon, improvements in $\mathrm{pH}$, decreased bulk density, improved soil porosities and water-holding capacities, increased microbial populations and dehydrogenase activity of soils in response to vermicompost treatments were observed [37]. The use of organic amendments has been recognized generally as an effective means for improving soil physical and chemical properties [43, 28]. However, limited researches were conducted on the effects of lime and organic matter application on soil acidity management in the highlands of East Wollega Zone, of Oromia Regional State of Ethiopia.

Therefore, by considering the beneficial effects of liming and organic matter as an amendment for soil acidity reclamation, the objective of this study was:

To assess the combined effects of lime and vermicompost on selected soil properties of Nitisols in Negasa area of East Wollega Zone, Ethiopia.

\section{Materials and Methods}

\subsection{Study Sites}

The study was conducted on the farmer's field of bread wheat land use in Negasa Peasant Association found in Guto Gida district in East Wollega Zone of Oromia Regional State, Ethiopia. Guto Gida district is located at a distance of about $331 \mathrm{~km}$ west of Addis Ababa, while Negasa Peasant Association is about $30 \mathrm{~km}$ from Nekemte town in south western direction. The district is situated at an altitude of 1500 - 2170 masl and lies between $8^{\circ} 57^{\prime} 43.4^{\prime \prime}$ and $9^{\circ} 30^{\prime}$ 58.5” N latitude and $36^{\circ} 26^{\prime} 25.24^{\prime \prime} \mathrm{E}$ and $36^{\circ} 44^{\prime} 419.58^{\prime \prime} \mathrm{E}$ longitude. (using Ethio Maping Agency). The specific study site is situated at an altitude of 2018 masl and geographically lies at $09^{\circ} 2^{\prime} 11.76^{\prime \prime} \mathrm{N}$ latitude and $36^{\circ} 34^{\prime} 43.5^{\prime \prime}$ E longitude according to Garmin 60 GPS reading.

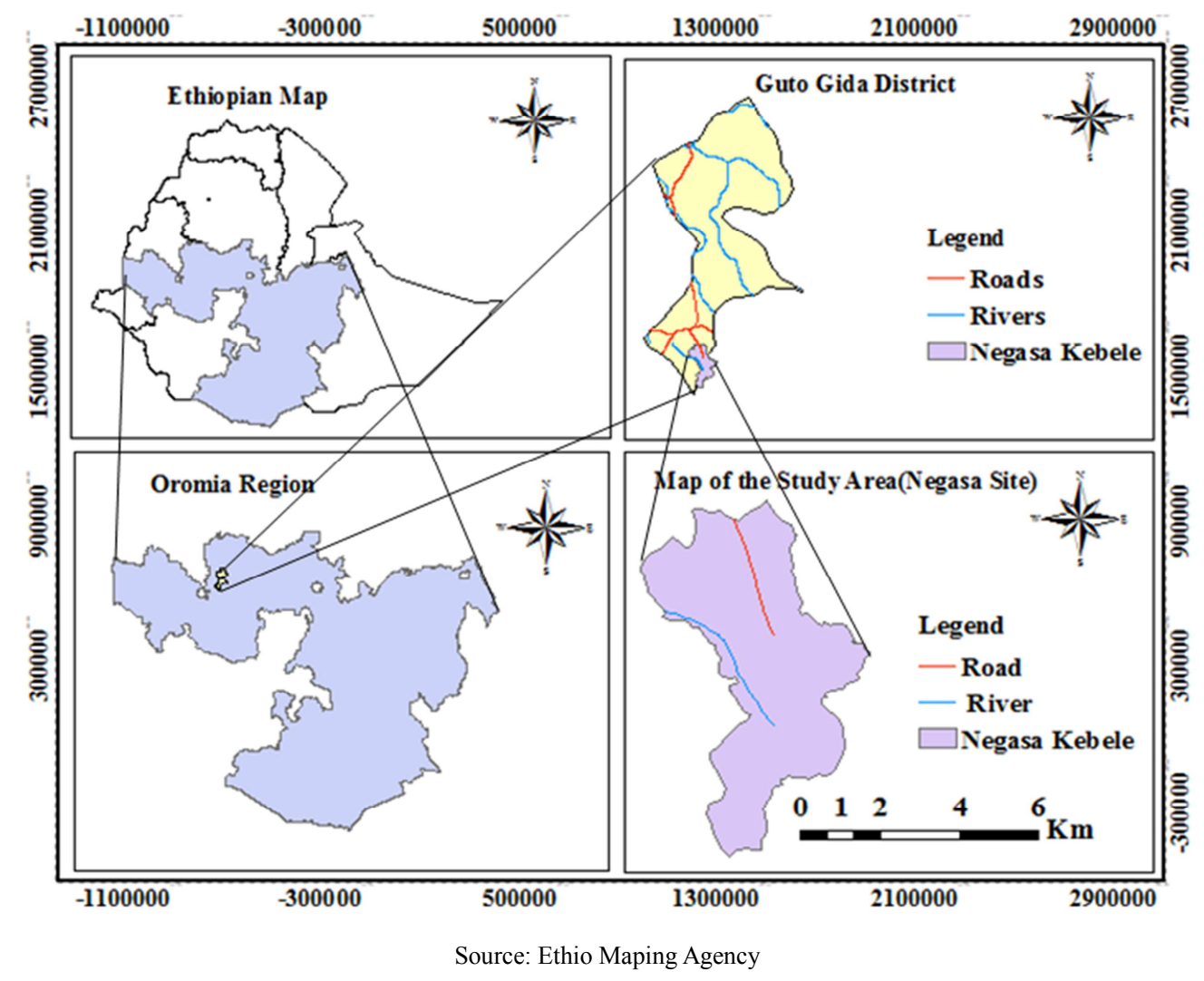

Figure 1. Map and location of the study area.

The agro-climatic zone of Guto Gida district is highland (baddaa), midland (Badda daree) and lowland (gammmoojjii). According to the ten years (2007 - 2016) weather data recorded at the Nekemte Meteorological Station, the average annual rainfall of the study area is $2204.1 \mathrm{~mm}$ and the monthly mean minimum and maximum temperatures ranges between 11.90 to 14.30 and 20.30 to $27.00^{\circ} \mathrm{C}$ with unimodal rainfall pattern with monthly mean maximum rainfall $(403.40 \mathrm{~mm})$ received in the month of August. While the average annual minimum and maximum temperatures of the district are 13.1 and $23.5^{\circ} \mathrm{C}$, respectively (Figure 2). 


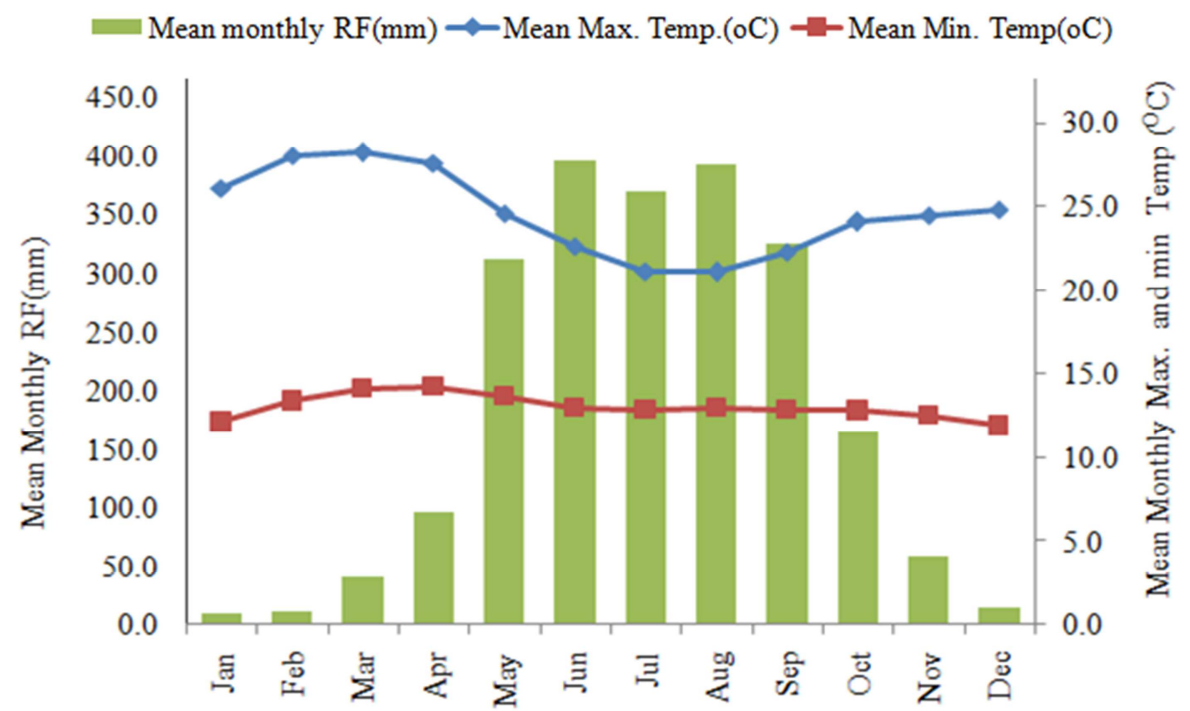

Figure 2. Mean monthly rainfall (mm) and Mean monthly minimum and maximum temperatures $\left({ }^{\circ} \mathrm{C}\right)$ of the study area $(2007-2016)$.

According to Food and Agricultural Organization (2014) classification, the dominant soil type in the study area is nitisols [26]. The major crops grown in the area includes but not limited to; coffee (Coffee arabica), wheat (Triticum Aestivum L.), teff (Eragrostis tef), barley (Hordeum vulgaris), maize (Zea mays), potato (Solanum tubersoum) and hot pepper (Capsicum annum) [15].

\subsection{Site Selection}

The study site, Negasa area in Guto Gida district was selected for gradual crop production and its rapid acidification. One field which has lower soil pH-H2O (4.91) was selected from five previously selected fields for the study purpose.

\subsection{Soil Sampling and Analysis Before Planting}

After deciding the specific experimental site, soil sampling points in the experimental field were selected following the zigzag soil sampling point selection pattern. Accordingly, 10 soil samples were collected from the experimental field at the depth $0-20 \mathrm{~cm}$ by using auger. One composite sub-sample was prepared from the bulk samples for the determination of soil physicochemical properties before lime and vermicompost application. One undisturbed soil sample from the experimental site for bulk density determination was taken by using $20 \mathrm{~cm}$ height core sampler. The soil bulk density and exchangeable acidity were used to determine the rates of lime applied. Recommended rate of lime application was determined using exchangeable acidity method [51].

Bulk density of the soil was determined using the core method by weighing undisturbed oven dried soil sample. The composite soil sample was air-dried, ground and passed through a $2 \mathrm{~mm}$ sieve before analysis in the laboratory. Soil texture was determined by Bouyoucos hydrometer method [27]. Soil $\mathrm{pH}$ was measured potentiometrically using a $\mathrm{pH}$ meter with glass electrode in the supernatant suspension of 1:2.5 soils to water ratio [6]. Total $\mathrm{N}$ of soil was analyzed using the Kjeldahl digestion, distillation and titration method [7]. Organic carbon was determined by wet oxidation method. Available phosphorus was determined by using Olsen et al. (1954) method [47]. The soil exchangeable acidity was measured by saturating the soil samples with potassium chloride solution and titrating with sodium hydroxide [40]. Percent acid saturation (PAS) was estimated as:

$$
\text { Percent acid saturation } \%=\frac{\text { Exachengeable acidity }(\mathrm{cmol}(+) / \mathrm{Kg}}{\text { Effective } \mathrm{CEC}(\mathrm{cmol}(+) / \mathrm{Kg}} * 100
$$

To determine the cation exchange capacity (CEC) of the soil, soil sample was first leached with $1 \mathrm{M} \mathrm{NH}_{4} \mathrm{OAc}$ solution buffered at $\mathrm{pH}$ 7. The ammonium saturated soil sample was washed with ethanol and the adsorbed ammonium was replaced by sodium ions [13]. The quantity of the ammonium ions replaced by sodium ions was estimated by ammonia distillation into dilute sulfuric acid. Distillate was back titrated with dilute acid and the quantities of ammonium ions were expressed as CEC of the soil. Exchangeable $\mathrm{Ca}$ and $\mathrm{Mg}$ of the soil in the extracts were analyzed using atomic absorption spectrophotometer, while $\mathrm{Na}$ and $\mathrm{K}$ were analyzed by flame photometer $[13,48]$. The soil percent base saturation (PBS) was calculated from sum of the basic exchangeable cations $(\mathrm{Ca}, \mathrm{Mg}, \mathrm{K}$ and $\mathrm{Na})$ as the percentage of CEC.

\subsection{Vermicompost Characterization}

The $\mathrm{pH}$ of vermicompost were measured using a $\mathrm{pH}$ meter glass electrode and in the extract of the saturated vermicompost [6], while electrical conductivity (EC) is determined with conductivity cell in extract of the saturated vermicompost. Nitrogen of vermicompost was analyzed using the Kjeldahl digestion, distillation and titration method [7]. Ash content of vermicompost was determined in a muffle 
oven at $550^{\circ} \mathrm{C}$ for $3 \mathrm{hr}$. Phosphorus content of vermicompost was analyzed using Chapman and Pratt (1961) method [13].

\subsection{Experimental Design and Procedures}

The experimental design was randomized complete block design with three replications. Treatments were lime $\left(\mathrm{CaCO}_{3}\right)$ with four levels $(0,50,100$ and $150 \%$ of recommended rate using exchangeable acidity method) and vermicompost with three levels $\left(0,2.5\right.$ and $\left.5 \mathrm{t} \mathrm{ha}^{-1}\right)$. The experiment was conducted in $4 \times 3$ factorial arrangements.

The field experiment was conducted in 2018 cropping season. The land was prepared using hand hoe (three times ploughing) before lime and vermicompost application. Lime and vermicompost were uniformly surface broadcasted and then incorporated to the respective plots within $20 \mathrm{~cm}$ soil depth. Wheat digalu variety was planted after a month of lime application and two weeks of vermicompost application.

\subsection{Post Harvest Soil Sampling and Analysis}

One composite sample was prepared from the five samples collected per plot. One undisturbed soil sample was collected from each plot using core sampler of $15 \mathrm{~cm}$ height for determination of bulk density of the soil. The samples were air-dried, ground and passed through a $2 \mathrm{~mm}$ sieve before analysis. Analysis of the selected soil physicochemical properties were carried out as the same as that of before planting described above.

\subsection{Statistical Data Analysis}

Data recorded were subject to analysis of variance (General Linear Model (GLM) procedure) using SAS software [49] to test treatments effect on selected soil chemical properties. Means of treatment effects were separated using the Duncan's Multiple Range Test (DMRT) comparison at $\mathrm{p} \leq 0.05$. Correlation analyses were carried out to detect the magnitude and degree of relationships among key soil variables.

\section{Results and Discussion}

\subsection{Physical Properties of Experimental Soil Before Planting}

Soil particle size distribution: The particles size distribution of the soil of the experimental site was found to be $27 \%$ clay, $37 \%$ sand and $36 \%$ silt (Table 1). Accordingly, the textural class of the soil is clay loam. Soil texture is one of the inherent soil properties less affected by management and which determines nutrient status, organic matter content, air circulation and water holding capacity of a given soil. Clay loam soil is suitable for crop production because it can hold sufficient water and contains a great deal of nutrients that are useful for plants [35].

Soil bulk density: Before planting, soil bulk density value was $1.29 \mathrm{~g} \mathrm{~cm}^{-3}$, which is low as per the rating suggested by Jones, C. A. 1983 for mineral soils [31]. This low bulk density value of the experimental soil might be due to the texture of the soil. In relation with its compactness soil of the experimental site was suitable for wheat production.

Table 1. Values for selected soil physical properties before planting.

\begin{tabular}{lllll}
\hline \multicolumn{2}{l}{ Particle size distribution (\%) } & $\begin{array}{l}\text { Textural } \\
\text { class }\end{array}$ & $\begin{array}{l}\text { Bulk } \\
\text { density }\end{array}$ \\
\hline Sand & Silt & Clay & Clay loam & $1.29 \mathrm{~cm}^{-3}$ \\
\hline 37 & 36 & 27 & &
\end{tabular}

\subsection{Selected Soil Chemical Properties Before Planting}

Soil reaction $(\mathrm{pH})$ : Soil $\mathrm{pH}$ of the experimental site before planting was 4.91. According to [16] rating, the soil reaction of the experimental site was very strongly acidic (Table 2) which is not suitable for the growth of most crops. Soil $\mathrm{pH}$ result clearly indicated that the value was below the described range and the soil was not suitable for most crop production with regard to $\mathrm{pH}$. For optimum crop production, the soil $\mathrm{pH}$ should be adjusted to the desired range through management intervention.

Organic carbon: The organic carbon content of experimental soil before sowing was $1.45 \%$ (Table 2 ) which was rated as low [38]. This low organic carbon content of the soil might be due to low input of organic sources such as animal manure, compost and household wastes. Farmers of the area also remove crop residues from the cultivated fields for fuel and animal feeds. To improve soil properties and productivity, organic amendment of soil of the study area is vital.

Total nitrogen: The total nitrogen content of the soil before planting was $0.13 \%$ (Table 2 ), which was rated as moderate [38]. Total nitrogen cannot be used as a measure of the mineralized forms of nitrogen $\left(\mathrm{NH}_{4}^{+}, \mathrm{NO}_{3}^{-}\right.$, and $\left.\mathrm{NO}_{2}^{-}\right)$as much of it is held in the organic matter in the soil.

Available phosphorus: Phosphorus level of experimental soil before planting was $3.15 \mathrm{ppm}$ (Table 2). According to Chude et al. (2005) rating, available soil P level of the study site was very low ( $<5 \mathrm{ppm})$ [17]. This low available phosphorus could be due to fixation in such acidic soils. [38] and Dawit et al. (2002) reported that availability of $\mathrm{P}$ in most soils of Ethiopia decline by the impacts of fixation as a result of low $\mathrm{pH}$. In order to increase bioavailability of $\mathrm{P}$ in such soil, increase in soil $\mathrm{pH}$ is the best management option to minimize fixation.

Table 2. Soil pH, organic carbon, total nitrogen and available phosphorus before planting.

\begin{tabular}{llll}
\hline Soil properties & Value & Rating & References \\
\hline $\mathrm{pH}($ water$)$ & 4.91 & Very strongly acidic & {$[16]$} \\
Available $\mathrm{P}(\mathrm{ppm})$ & 3.15 & Very low & {$[17]$} \\
Organic C $(\%)$ & 1.45 & Low & {$[39]$} \\
Total N $(\%)$ & 0.13 & Moderate & {$[38]$} \\
\hline
\end{tabular}

Where $\mathrm{pH}=$ Power of hydrogen activity $\left(1: 2.5 \mathrm{H}_{2} \mathrm{O}\right) ; \quad \mathrm{P}=\mathrm{Phosphorus}$; $\mathrm{C}=$ Carbon; $\mathrm{N}=$ Nitrogen and $\mathrm{ppm}=$ Parts per million.

Exchangeable acidity (EA): It indicates the presence of excess $\mathrm{Al}^{3+}$ and $\mathrm{H}^{+}$ion on the soil colloid as compared to total cation exchange capacity of the soil. The exchangeable acidity of experimental soil before planting was $8.06 \mathrm{cmol} \mathrm{(+)}$ $\mathrm{kg}^{-1}$ (Table 3). It is very high $\left(>7.5 \mathrm{cmol}(+) \mathrm{kg}^{-1}\right)$ according 
to Daryl D (1983) rating [20].

Exchangeable bases: Results indicated that exchangeable $\mathrm{Mg}$ was the dominate cation followed by $\mathrm{Ca}$ (Table 3 ). As per the ratings of Food and Agriculture Organization (2006), the exchangeable $\mathrm{Ca}$ was low while exchangeable $\mathrm{Mg}$ was high [25]. Concentrations of exchangeable $\mathrm{K}$ and $\mathrm{Na}$ of the experimental soil were medium and very low respectively. Low value of exchangeable $\mathrm{Ca}$ implies amendment of $\mathrm{Ca}$ as liming material is important. Soil with low exchangeable $\mathrm{Ca}$ can be productive soil through appropriate managements such as liming [9].

Cation exchange capacity (CEC): The result showed that the cation exchange capacity of the experimental soil was $35.01 \mathrm{cmol}(+) \mathrm{kg}-1$ (Table 3). As per the rating of Hazelton and Murphy (2007), the CEC of the soil was high [29]. The soil with a higher CEC may not necessarily be more fertile; because the soil's CEC can be occupied by acid cations such as hydrogen $\left(\mathrm{H}^{+}\right)$and aluminum $\left(\mathrm{Al}^{3+}\right)$ that might be the reason for the higher CEC value of the experimental soil.

Table 3. Exchangeable properties of the experimental soil before planting Soil properties.

\begin{tabular}{llll}
\hline Soil properties & Value & Rating & References \\
\hline $\mathrm{EA}\left(\mathrm{cmol}(+) \mathrm{kg}^{-1}\right)$ & 3.06 & Very low & {$[20]$} \\
$\mathrm{ECa}\left(\mathrm{cmol}(+) \mathrm{kg}^{-1}\right)$ & 4.33 & Low & {$[25]$} \\
$\mathrm{EMg}\left(\mathrm{cmol}(+) \mathrm{kg}^{-1}\right)$ & 5.27 & High & {$[25]$} \\
$\mathrm{EK}\left(\mathrm{cmol}(+) \mathrm{kg}^{-1}\right)$ & 0.45 & Medium & {$[25]$} \\
$\mathrm{ENa}\left(\mathrm{cmol}(+) \mathrm{kg}^{-1}\right)$ & 0.04 & Very low & {$[25]$} \\
$\mathrm{CEC}\left(\mathrm{cmol}(+) \mathrm{kg}^{-1}\right)$ & 35.01 & High & {$[29]$} \\
\hline
\end{tabular}

Where EA=Exchangeable acidity; ECa $=$ Exchangeable calcium; EMg = Exchangeable magnesium; $\mathrm{EK}=$ Exchangeable potassium; $\mathrm{ENa}=$ Exchangeable sodium and $\mathrm{CEC}=$ Cation exchange capacity

\subsection{Vermicompost Analysis Results}

The chemical analytical results for vermicompost sample are shown in (Table 4). The vermicompost had $\mathrm{N}$ and $\mathrm{P}$ of $(1.51 \%)$ and $(0.02 \%)$ respectively. The vermicompost's $\mathrm{pH}$ was moderately alkaline (7.66) and had organic Carbon of $(17.15 \%)$ and a narrow $\mathrm{C}: \mathrm{N}$ ratio (11:36). The narrow C: $\mathrm{N}$ ratio of this vermicompost means well for net mineralization for nutrients such $\mathrm{N}$ and $\mathrm{p}$, and therefore their availability in soil for plant use [29]. The less acidic nature of this vermicompost was desirable in increasing the productivity such acidic soil.

Table 4. Selected chemical properties of the vermicompost before plantation.

\begin{tabular}{ll}
\hline Parameters & Value \\
\hline $\mathrm{pH}\left(1: 2.5 \mathrm{H}_{2} \mathrm{O}\right)$ & 7.66 \\
$\mathrm{C}(\%)$ & 17.15 \\
$\mathrm{~N}(\%)$ & 1.51 \\
$\mathrm{C}: \mathrm{N}$ & 11.36 \\
$\mathrm{P}(\%)$ & 0.02 \\
$\mathrm{EC}\left(\mathrm{mS} \mathrm{cm}^{-1}\right)$ & 2.63 \\
\hline
\end{tabular}

Where $\mathrm{pH}=$ Power of hydrogen activity; $\mathrm{C}=$ Carbon; $\mathrm{N}=$ Nitrogen; $\mathrm{P}=\mathrm{Phosphorus}$ and $\mathrm{EC}=$ Electrical conductivity. 4.3. Lime and Vermicompos $t$ Amendment Effects on Selected Soil Physical and chemical Properties

\subsection{Soil Bulk Density, Organic Matter, Total N, Carbon to Nitrogen Ratio and Available P as Affected by the Treatments}

Soil Bulk Density: Analysis of variance (ANOVA) revealed that the main effects of lime and vermicompost rates were highly and significantly $(\mathrm{P} \leq 0.01)$ influenced the mean value of soil bulk density. The interaction effect also statistically significant at $\mathrm{P} \leq 0.01$.

The mean value of the soil bulk density obtained decreased with increasing both lime and vermicompost rate applied. Maximum soil bulk density $\left(1.475 \mathrm{~g} \mathrm{~cm}^{-3}\right)$ was recorded at the control plot; while the minimum $\left(1.053 \mathrm{~g} \mathrm{~cm}^{-3}\right)$ was at combined application of the highest recognized rates of both factors (Table 5). This attributes to combination of vermicompost with lime increases the porosity of soil, which ultimately promotes water holding capacity of the soil.

The decrease in the bulk density of the soil to the increased rate of lime could be lime's ability to increase soil total porosity. The result obtained is consistent with the findings of Carmeis et al. (2018) and Mittra et al. (2003), who reported that the bulk density under treatment combination of fly ash (lime) along with paper factory sludge or chemical fertilizer was reduced while it remained unchanged in the control plot $[12,41]$. Decrease in soil bulk density compared to the control due to the application of vermicompost was also reported by [37].

Table 5. Interaction effect of Lime and vermicompost rates on soil bulk density $\left(\mathrm{g} \mathrm{cm}^{-3}\right)$.

\begin{tabular}{llll}
\hline \multirow{2}{*}{$\mathrm{CaCO}_{3}(\% \mathbf{R R})$} & \multicolumn{4}{l}{ Vermicompost $\left(\mathbf{t ~ h a}^{-1}\right)$} \\
\cline { 2 - 4 } & $\mathbf{0}$ & $\mathbf{2 . 5}$ & $\mathbf{5}$ \\
\hline 0 & $1.475^{\mathrm{a}}$ & $1.306^{\mathrm{bc}}$ & $1.236^{\mathrm{bcd}}$ \\
50 & $1.295^{\mathrm{bc}}$ & $1.119^{\text {ed }}$ & $1.309^{\mathrm{bc}}$ \\
100 & $1.362^{\mathrm{ab}}$ & $1.107^{\mathrm{ed}}$ & $1.080^{\mathrm{e}}$ \\
150 & $1.206^{\mathrm{cde}}$ & $1.121^{\mathrm{de}}$ & $1.053^{\mathrm{f}}$ \\
LSD (5\%) & 0.14 & & \\
CV (\%) & 6.80 & & \\
\hline
\end{tabular}

Interaction mean with in rows and columns with the same letter are not significantly different at $(\mathrm{p} \leq 0.05)$; Where $\mathrm{CaCO}_{3}=$ Agricultural lime; $\mathrm{RR}=$ Recommended rate; $\mathrm{LSD}=$ Least significant difference and $\mathrm{CV}=$ Coefficient of variation.

Organic Matter and Total Nitrogen: Even though Organic matter and total nitrogen of experimental soil slightly increased with increasing lime and vermicompost rate application; the statistical analysis has indicated that the increment of these both soil indices and $\mathrm{C}: \mathrm{N}$ ratio were statistically insignificant. Also the interaction effect of both factors on organic matter and carbon nitrogen ratio were statistically insignificant, while significant $(\mathrm{P} \leq 0.05)$ on total nitrogen contents of the soil.

The most probable reasons for the minimum change of total nitrogen due to the application of lime and vermicompost may be due to mineralization, availability to plant up take and high rainfall of the area, which enhances losses of $\mathrm{N}_{2}$ from the soil. Net $\mathrm{N}$ mineralization was enhanced significantly as lime and compost was applied either solely or in combination [18 and 2]. From earlier studies it is also, evident that vermicompost 
provides $\mathrm{N}_{2}$ in readily available form and enhances up take by plants [5]. Liming also improves biological $\mathrm{N}_{2}$ fixation in acid soils and enhances net mineralization of organic $\mathrm{N}_{2}$ [23] which also make it readily available to plant up take. Therefore, Nitrification and mineralization due to lime and vermicompost application could increases $\mathrm{N}_{2}$ losses from the soil via leaching and plant up take.

Effects of liming on net $\mathrm{N}_{2}$ mineralization has attributed to a reduction of $\mathrm{Al}$ toxicity and an increase in soil $\mathrm{pH}$ that can both result in an increase of total microbial activity and a release of labile organic matter [1, 30]. Vermicompost used in the experiment might also be a source of soil nitrifiers and decomposers. These may be the reason for insignificance effects of lime and vermicompost rates on organic matter contents and carbon nitrogen ratio of soils.

Table 6. Main effects of lime and Vermicompost rates, on soil OM, C: N, Av. $P$ and $p H$.

\begin{tabular}{lllll}
\hline \multirow{2}{*}{ Treatment } & \multicolumn{4}{l}{ Soil chemical properties } \\
\cline { 2 - 5 } OM (\%) & $\mathbf{C : N}$ & $\mathbf{A v P}(\mathbf{p p m})$ & $\mathbf{p H}\left(\mathbf{1 : 2 . 5} \mathbf{H}_{\mathbf{2}} \mathbf{O}\right)$ \\
\hline$\left(\mathrm{CaCO}_{3} \% \mathrm{RR}\right)$ & & & & \\
0 & 3.06 & 9.53 & 2.94 & $4.99^{\mathrm{b}}$ \\
50 & 3.08 & 9.56 & 3.54 & $5.06^{\mathrm{ab}}$ \\
100 & 3.19 & 9.60 & 3.40 & $5.37^{\mathrm{a}}$ \\
150 & 3.18 & 9.51 & 3.91 & $5.37 \mathrm{a}$ \\
Significance & $\mathrm{ns}$ & $\mathrm{ns}$ & $\mathrm{ns}$ & $* *$ \\
LSD (5\%) & 0.35 & 0.88 & 1.32 & 0.33 \\
VcR (t ha $\left.{ }^{-1}\right)$ & & & & \\
0 & 3.11 & 9.69 & 3.30 & 5.15 \\
2.5 & 3.14 & 9.59 & 3.40 & 5.22 \\
5 & 3.16 & 9.46 & 3.65 & 5.23 \\
Significance & $\mathrm{ns}$ & $\mathrm{ns}$ & $\mathrm{ns}$ & $\mathrm{ns}$ \\
LSD (5\%) & 0.20 & 0.92 & 1.15 & 0.28 \\
CV $(\%)$ & 6.70 & 19.22 & 39.53 & 6.46 \\
\hline
\end{tabular}

Where $\quad \mathrm{CaCO}_{3}=$ Agricultural lime; $\mathrm{RR}=$ Recommended rate; $\mathrm{VcR}=$ Vermicompost rate; $\mathrm{LSD}=$ Least significant difference; $\mathrm{CV}=$ Coefficient of variation; $\mathrm{ns}=\mathrm{Not}$ significant; $* *=$ Significant different at $\mathrm{p} \leq 0.05$; $* * *=$ Highly and significantly different at $\mathrm{p} \leq 0.01 ; \mathrm{OM}=$ Organic matter; $\mathrm{C}$ : $\mathrm{N}=$ Carbon nitrogen ratio; $\mathrm{AvP}=$ Available phosphorus; $\mathrm{pH}=$ power of hydrogen and $\mathrm{ppm}=$ parts per million.

In Table 7 indicates that combined application of vermicompost with lime increase soil nitrogen content, which ultimately promotes plant growth and production at sustainable basis.

Table 7. Interaction effect of Lime and vermicompost rates on total nitrogen of soil (\%).

\begin{tabular}{llll}
\hline \multirow{2}{*}{$\mathrm{CaCO}_{3}(\% \mathbf{R R})$} & \multicolumn{4}{l}{ Vermicompost $\left(\mathbf{t ~ h a}^{-1}\right)$} \\
\cline { 2 - 4 } & $\mathbf{0}$ & $\mathbf{2 . 5}$ & $\mathbf{5}$ \\
\hline 0 & $0.164^{\mathrm{c}}$ & $0.193^{\mathrm{a}}$ & $0.201^{\mathrm{a}}$ \\
50 & $0.189^{\mathrm{ab}}$ & $0.170^{\mathrm{bc}}$ & $0.201^{\mathrm{a}}$ \\
100 & $0.199^{\mathrm{a}}$ & $0.195^{\mathrm{a}}$ & $0.183^{\mathrm{abc}}$ \\
150 & $0.191^{\mathrm{ab}}$ & $0.201^{\mathrm{a}}$ & $0.189^{\mathrm{ab}}$ \\
$\mathrm{LSD} \mathrm{(5 \% )}$ & 0.022 & & \\
CV $(\%)$ & 6.77 & & \\
\hline
\end{tabular}

Interaction mean within rows and columns with the same letter are not significantly different at $(\mathrm{p} \leq 0.05)$; Where $\mathrm{CaCO}_{3}=$ Agricultural lime; $\mathrm{RR}=$ Recommended rate; $\mathrm{LSD}=$ Least significant difference and $\mathrm{CV}=$ Coefficient of variation.

Available Phosphorus: The statistical analysis indicated that available $\mathrm{P}$ content of the experimental soil was not significantly affected by the main effects of both lime and vermicompost rates. The interaction effects of lime and vermicompost also insignificantly influenced the average available $P$ contents of the soil.

Lack of significant difference of this fertility status observed in this study could be attributed to the fact that applying lime and compost enhances nutrient mineralization and availability to plant up take. Liming acid soils enhance release of $\mathrm{P}$ from soil and make it readily available for plant uptake. Bolan et al. (20013) reported that in soils high in exchangeable acidity, liming might increase plant $\mathrm{P}$ uptake by decreasing $\mathrm{Al}$, rather than by increasing $\mathrm{P}$ availability per se [10]. This might be due to improved root growth where $\mathrm{Al}$ toxicity is alleviated, allowing a greater volume of soil for root elongation.

Soil $\mathrm{pH}$ : ANOVA revealed statistically significant $(\mathrm{P} \leq$ 0.05 ) differences due to main effect of applied lime rates on soil $\mathrm{pH}$. However, the main effect of vermicompost and interaction effect of both factors were not statistically significant.

Soils amended with lime had higher $\mathrm{pH}$ than the un amended soil. The increased soil $\mathrm{pH}$ values due to liming may partly be due to the replacement of $\mathrm{H}^{+}$and $\mathrm{Al}^{3+}$ ions on the clay surfaces with $\mathrm{Ca}$ from lime through neutralization of the acidity. The other most probable reasons for increment of soil $\mathrm{pH}$ with increasing lime rate is due to greater pore continuity or enhanced earthworm activity in dissolved soil systems [8].

The findings observed are comparable to the findings of Asrat et al. (2014) who reported that application of 11.2 tons $\mathrm{ha}^{-1}$ of $\mathrm{CaCO}_{3}$ significantly $(\mathrm{P} \leq 0.001)$ increased the soil $\mathrm{pH}$ from 4.89 to 6.03 and reduced the exchangeable acidity from 2.22 to 0.14 cmolc $\mathrm{kg}^{-1}$ [4]. The $\mathrm{pH}$ increase with liming in this study is also consistent with the findings of Dikinya and Mufwanzala (2010) who reported favorable pH changes in soil when lime was applied to the soil of soybean field [22].

\subsection{Exchangeable Bases, Exchangeable Acidity and Cation Exchangeable Capacity as Affected by Treatments}

Exchangeable Bases: Analysis of variance showed the main effect of lime rates significantly $(\mathrm{P} \leq 0.05)$ influenced exchangeable $\mathrm{Ca}, \mathrm{Mg}, \mathrm{K}$ and $\mathrm{Na}$. The main effect of vermicompost rates on exchangeable $\mathrm{Mg}, \mathrm{K}$ and $\mathrm{Na}$ was significant $(\mathrm{p} \leq 0.05)$. Exchangeable $\mathrm{Ca}, \mathrm{Mg}, \mathrm{K}$ and $\mathrm{Na}$ were not significantly influenced by the interaction effect of both factors.

Exchangeable $\mathrm{Mg}$ showed significant decrease with increasing the lime rates. The reduction of exchangeable $\mathrm{Mg}$ with increased lime rates might be associated with the increased concentration of $\mathrm{Ca}^{2+}$. $\mathrm{Mg}$ is a poor competitor with $\mathrm{Al}$ and $\mathrm{Ca}$ for the exchange sites [44]. Pearson's simple correlation analysis has showed highly significant $(\mathrm{P} \leq 0.01)$ and negative correlation of exchangeable $\mathrm{Mg}$ with soil exchangeable $\mathrm{Ca}(\mathrm{r}=-$ $0.57^{* * *}$ ) (Table 9).

Exchangeable $\mathrm{Ca}, \mathrm{K}$ and $\mathrm{Na}$ were significantly increased with increasing the lime rates. The increase in these soil indices could be attributed to application of limestone 
(calcium carbonate) to acid soils that raises the soil $\mathrm{pH}$, resulting in enhanced activities of exchangeable bases [46]. Chimdi et al.(2012b) also reported that soil treated with different lime rates $\left(2,4,6,8\right.$ and $\left.10 \mathrm{tha}^{-1}\right)$ showed increase in concentration of basic ions and reduction of exchangeable acidity [15]. Increased application of vermicompost rates increases the soil exchangeable $\mathrm{Mg}, \mathrm{k}$ and $\mathrm{Na}$. These might be due to alkalinity nature of vermicompost resulted in increasing basic cations.

Exchangeable Acidity: ANOVA showed that the main effect of lime rates significantly $(P \leq 0.01)$ influenced soil exchangeable acidity. However, the main effect of vermicompost and interaction effect of both factors were not significant on soil exchangeable acidity.

Exchangeable acidity decreased with increasing lime rates. The decrement of exchangeable acidity with increasing lime rates might be associated with the replacement of $\mathrm{H}^{+}$and $\mathrm{Al}^{3+}$ ions on the clay surfaces with $\mathrm{Ca}$ from the agricultural lime subsequently increment of soil $\mathrm{pH}$ [53].

Soil Cation Exchange Capacity (CEC): ANOVA showed that CEC was not significantly influenced by the main and interaction effects of lime and vermicompost rates. The change in soil CEC due to lime and vermicompost application is minimum and statistically insignificant. It might be due to addition of lime and vermicompost facilitates organic matter decomposition that make may decrease soil CEC.

Table 8. Main effects of lime and vermicompost rates on soil exchangeable bases, exchangeable acidity and cation exchange capacity.

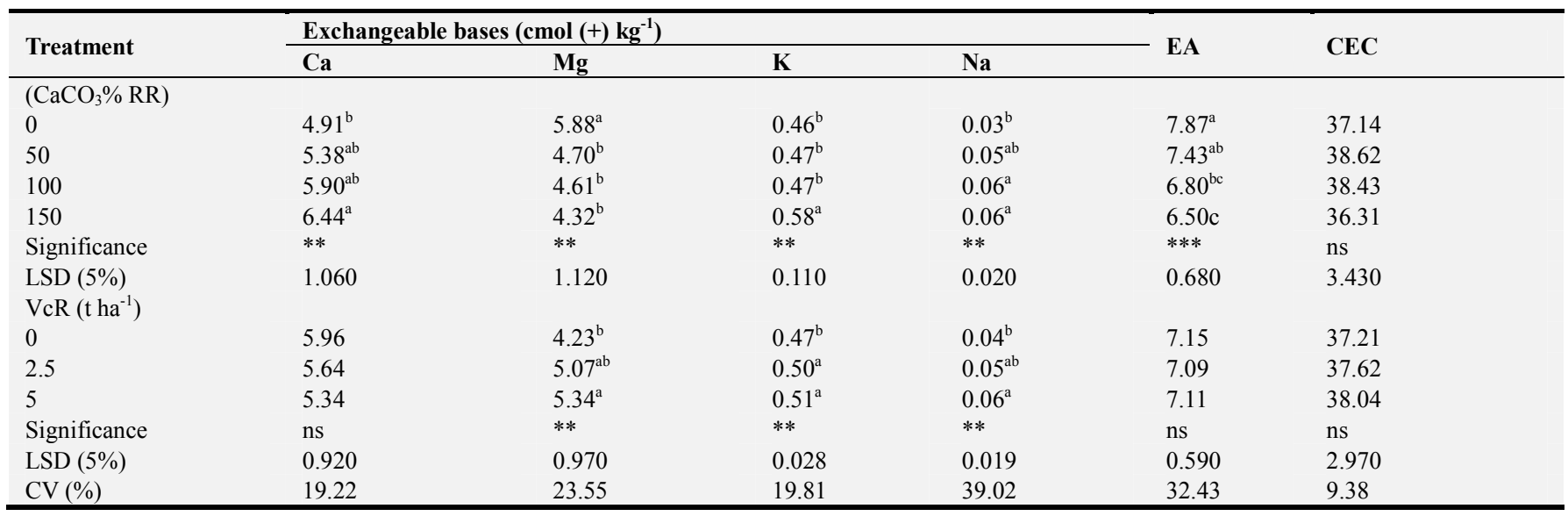

Where $\mathrm{CaCO}_{3}=$ Agricultural lime; $\mathrm{RR}=$ Recommended rate; $\mathrm{VcR}=$ Vermicompost rate; $\mathrm{LSD}=$ Least significant difference; $\mathrm{CV}=\mathrm{Coefficient}$ of variation; ns=Not significant; $* *=$ Significant different at $\mathrm{p} \leq 0.05 ; * * *=$ Highly and significantly different at $\mathrm{p} \leq 0.01 ; \mathrm{Ca}=\mathrm{Calcium} ; \mathrm{Mg}=\mathrm{Magnesium} ; \mathrm{K}=\mathrm{Potassium}$; $\mathrm{Na}=\mathrm{Sodium}$; $\mathrm{EA}=$ Exchangeable acidity in $\mathrm{cmol}(+) \mathrm{kg}^{-1}$ and $\mathrm{CEC}=$ Cation exchange capacity in $\mathrm{cmol}(+) \mathrm{kg}^{-1}$.

\subsection{Correlation Analysis Among Selected Soil Properties}

The correlation analysis indicates that the soil $\mathrm{pH}\left(\mathrm{H}_{2} \mathrm{O}\right)$ is significantly $(\mathrm{P} \leq 0.01)$ and negatively correlated with exchangeable acidity $\left(\mathrm{r}=-0.65^{* * *}\right)$ but significantly $(\mathrm{P} \leq 0.01)$ and positively correlated with available $\mathrm{P}\left(\mathrm{r}=0.45^{* * *}\right)$. Exchangeable acidity was negatively and significantly correlated with exchangeable $\mathrm{Ca}$ and $\mathrm{Na}$ with correlation coefficient values of $-0.64 * * *$ and $-0.36 * *$ respectively.

Exchangeable $\mathrm{Ca}$ and $\mathrm{Mg}$ have inverse relation with having $(\mathrm{r}=-0.57 * * *)$. Carbon nitrogen ratio was strongly significant $(\mathrm{p} \leq 0.01)$ and negatively correlated with total $\mathrm{N}$ $\left(\mathrm{r}=-0.73^{* * *}\right)$. It also significantly $(\mathrm{p} \leq 0.01)$ but positively correlated with organic matter contents of soil $\left(\mathrm{r}=0.5^{* * *}\right)$ and exchangeable $\mathrm{K}\left(\mathrm{r}=0.45^{* * *}\right)$ (Table 9$)$.

Table 9. Pearson's Correlation coefficient (r) among selected soil physicochemical properties.

\begin{tabular}{|c|c|c|c|c|c|c|c|c|c|c|c|c|}
\hline Variable & EA & BD & EMg & CEC & $\mathrm{C}: \mathrm{N}$ & OM & TN & AvP & ENa & EK & ECa & pH \\
\hline EA & 1 & & & & & & & & & & & \\
\hline $\mathrm{BD}$ & $0.22^{\mathrm{ns}}$ & 1 & & & & & & & & & & \\
\hline $\mathrm{EMg}$ & $0.44^{* * *}$ & $-0.07^{\mathrm{ns}}$ & 1 & & & & & & & & & \\
\hline CEC & $0.10^{\mathrm{ns}}$ & $0.15^{\mathrm{ns}}$ & $0.07^{\mathrm{ns}}$ & 1 & & & & & & & & \\
\hline $\mathrm{C}: \mathrm{N}$ & $-0.08^{\mathrm{ns}}$ & $0.32^{\mathrm{ns}}$ & $-0.21^{\mathrm{ns}}$ & $-0.05^{\mathrm{ns}}$ & 1 & & & & & & & \\
\hline OM & $-0.09^{\mathrm{ns}}$ & $-0.30^{\mathrm{ns}}$ & $-0.19^{\mathrm{ns}}$ & $0.52^{* * *}$ & $0.50^{* * *}$ & 1 & & & & & & \\
\hline $\mathrm{TN}$ & $-0.04^{\mathrm{ns}}$ & $-0.09^{\mathrm{ns}}$ & $0.11^{\mathrm{ns}}$ & $0.46^{* * *}$ & $-0.73^{* * *}$ & $0.22^{\mathrm{ns}}$ & 1 & & & & & \\
\hline AvP & $-0.28^{\mathrm{ns}}$ & $-0.22^{\mathrm{ns}}$ & $0.04^{\mathrm{ns}}$ & $-0.08^{\mathrm{ns}}$ & $0.08^{\mathrm{ns}}$ & $-0.07^{\mathrm{ns}}$ & $0.03^{\mathrm{ns}}$ & 1 & & & & \\
\hline $\mathrm{ENa}$ & $-0.36^{* *}$ & $-0.25^{\mathrm{ns}}$ & $-0.03^{\mathrm{ns}}$ & $0.16^{\mathrm{ns}}$ & $0.07^{\mathrm{ns}}$ & $0.04^{\mathrm{ns}}$ & $0.10^{\mathrm{ns}}$ & $0.01^{\mathrm{ns}}$ & 1 & & & \\
\hline EK & $-0.28^{n s}$ & $-0.35^{* *}$ & $-0.08^{\mathrm{ns}}$ & $0.17^{\mathrm{ns}}$ & $0.15^{\mathrm{ns}}$ & $0.30^{\mathrm{ns}}$ & $0.07^{\mathrm{ns}}$ & $0.22^{\mathrm{ns}}$ & $0.40^{\mathrm{ns}}$ & 1 & & \\
\hline $\mathrm{ECa}$ & $-0.64^{* * *}$ & $0.01^{\mathrm{ns}}$ & $-0.57^{* * *}$ & $0.04^{\mathrm{ns}}$ & $0.13^{\mathrm{ns}}$ & $0.30^{\mathrm{ns}}$ & $0.08^{\mathrm{ns}}$ & $0.26^{\mathrm{ns}}$ & $0.13^{\mathrm{ns}}$ & $0.22^{\mathrm{ns}}$ & 1 & \\
\hline $\mathrm{pH}$ & $-0.65^{* * *}$ & $-0.35^{* *}$ & $-0.11^{\mathrm{ns}}$ & $-0.06^{\mathrm{ns}}$ & $0.07^{\mathrm{ns}}$ & $0.02^{\mathrm{ns}}$ & $0.06^{\mathrm{ns}}$ & $0.45^{* * *}$ & $0.28^{\mathrm{ns}}$ & $0.30^{\mathrm{ns}}$ & $0.30^{\mathrm{ns}}$ & 1 \\
\hline
\end{tabular}

$* *=$ significant at $\mathrm{p} \leq 0.05$ and $* * *=$ significant at $\mathrm{p} \leq 0.01 ; \mathrm{EA}=$ Exchangeable acidity; $\mathrm{BD}=\mathrm{Bulk}$ density; EMg=Exchangeable magnesium; CEC $=\mathrm{Cation}$ exchange capacity; $\mathrm{C}$ : $\mathrm{N}=$ Carbon nitrogen ratio; $\mathrm{OM}=$ Organic matter; $\mathrm{TN}=$ Total nitrogen; AvP=Available phosphorus; ENa=Exchangeable sodium; $\mathrm{EK}=$ Exchangeable potassium; $\mathrm{ECa}=$ Exchangeable calcium and $\mathrm{pH}=$ Power of hydrogen activity. 


\section{Conclusion and Recommendation}

The study has revealed that most chemical properties especially acidity related properties more improved by lime amendment than vermicompost amendment. Soil $\mathrm{pH}$, and exchangeable acidity were significantly $(\mathrm{p} \leq 0.05)$ influenced by the main effect of lime rates but did not by the main effect of vermicompost rates. Exchangeable basic ions ( $\mathrm{K}, \mathrm{Na}$ and $\mathrm{Mg}$ ) and soil bulk density had significantly influenced by both lime and vermicompost; while Exchangeable Ca was significantly ( $p$ $\leq 0.05$ ) influenced only by the main effect of lime. Cation exchange capacity (CEC), available $\mathrm{P}, \mathrm{OM}$ contents, total $\mathrm{N}$ and $\mathrm{C}: \mathrm{N}$ of soil were not significantly influenced by the both factors Interaction effect of lime and vermicompost was significantly influenced $(\mathrm{p} \leq 0.05)$ soil bulk density and total nitrogen. The highest soil $\mathrm{pH}$ (5.37) and the lowest soil exchangeable acidity $\left(1.50 \mathrm{cmol}(+) \mathrm{kg}^{-1}\right)$ were recorded at sole application of the highest rate of lime (150\%RR).

Generally, ANOVA has shown that the Soil $\mathrm{pH}$ and exchangeable basic cations ( $\mathrm{Ca}, \mathrm{K}$ and $\mathrm{Na}$ ) have shown an increased with increasing lime rate applied. But soil exchangeable acidity and exchangeable $\mathrm{Mg}$ were decreased with increasing the rates of lime application. Exchangeable basic cations $(\mathrm{Mg}, \mathrm{K}$ and $\mathrm{Na})$ were increased significantly $(\mathrm{p} \leq 0.05)$ with increasing rate of vermicompost applied, while soil bulk density decreased. Therefore, it can be concluded that amendment of acidic soil more improved by lime application than vermicompost application. However, since the experiment was done for one season at one location, similar experiment has to be repeated over years to determine the long-term effect of lime and vermicompost on physicochemical properties of such acidic soil.

\section{Acknowledgements}

My heartfelt thank goes to the Oromia Agricultural Research Institute (OARI) for financial support of the field and laboratory work. I am thankful to Nekemte Soil Laboratory Research Center assistance soil chemist researcher, Ato Mintesinot Desalegn and all the Center laboratory and field technicians for their unlimited contribution in all aspects of the laboratory work from site selection up to the end. I also acknowledge the Laboratory technicians of National Soil Testing Center for their support during sample analysis. I am thankful to my families, especially my brothers Tolemariam Chimdessa and Alemayehu Chimdessa and my wife w/o Ayantu Tariku for supporting me in all means they could. Last but not least, my special thanks are reserved for my dad and mom for their strong moral support and good wish to my achievement.

\section{References}

[1] Andersson, S., Valeur, I., Nilsson, I., 1994. Influence of lime on soil respiration, leaching of DOC, and $\mathrm{C} / \mathrm{S}$ relationships in the mor humus of haplic podsol. Environmental International $20,81-88$.
[2] Andersson, S. 1999. Influence of liming substances and temperature on microbial activity and leaching of soil organic matter in coniferous forest ecosystem. Doctoral thesis. Swedish University of Agricultural Sciences.

[3] Anetor MO, Ezekie AA., 2007. Lime effectiveness of some fertilizers in a tropical acid alfisol", University of Ibadan, Ibadan, Nigeria; 2007.

[4] Asrat, M., Gebrekidan, H., Yli-Halla, M., Bedadi, B. and Negassa, W., 2014. Effect of integrated use of lime, manure and mineral $\mathrm{P}$ fertilizer on bread wheat (Triticum aestivum) yield, uptake and status of residual soil $\mathrm{P}$ on acidic soils of Gozamin District, north-western Ethiopia. Agriculture, Forestry and Fisheries, 3 (2), pp. 76-85.

[5] Atiyeh, R. M., Dominguez, J., Sobler, S. and Edwards, C. A. 2000. Changes in biochemical properties of cow manure during processing by earthworms (Eisenia andrei) and the effects on seedling growth. Pedobiologia, 44: 709-724.

[6] Barauah, T. C. and H. P., Barthakulh. 1997. A Text Book of Soil Analyses. Vikas Publishing House Pvt. Ltd. New Delhi, India.

[7] Black, C. A. 1965. Methods of soil analysis. Part I, American Society of Agronomy. Madison, Wisconsin, USA. 1572p.

[8] Bezdicek, D., John, H., Mary, F., Dennis, R. and Jon, M. 1998 Effects of long-term direct seeding on soil properties on Northwest farms. Proceedings, PNW direct seed cropping systems conference, January 7-8, Pasco WA, 1998. Boyd.

[9] Bohn, H., B. L. Meneal and G. A. O'connor. 2001. Soil Chemistry. 3rd ed. John Wiley and Sons, INC, pp. 207-233.

[10] Bolan, N. S. and Hedley, M. J. 2003. Role of carbon, nitrogen and sulfur cycles in soil acidification. In D. Marcel, In"Handbook of soil acidity" (pp. 29-56). New York: Rengel. $\mathrm{Z}$.

[11] Calba, H., Zonkeng, C., Ngonkeu, E. L. M., Adetimirin, V. O., Mafouasson, H. A., Meka, S. S. and Horst, W. J., 2006. Responses of maize grain yield to changes in acid soil characteristics after soil amendments. Plant and soil, 284 (12), pp. 45-57.

[12] Carmeis Filho, A. C., Crusciol, C. A., Guimarães, T. M., Calonego, J. C. and da Costa, C. H., 2018. Changes in soil physical properties and carbon protection mechanisms by surface application of lime in a tropical no-tillage system. Soil Science Society of America Journal, 82 (1), pp. 56-65.

[13] Chapman, H. D. and P. F., Pratt. 1961. Methods of analysis for soils, plants and water. Univ. California, Berkeley, Ca, USA.

[14] Chapman, H. D. 1965. Cation exchange capacity. In: C. A. Black, L. E. Ensminger and F. E. Clark (Eds). Methods of soil analysis. Am. Soc. Agro., 9: 891-901., Inc., Madison, Wisconsin.

[15] Chimdi, A., Gebrekidan, H., Kibret, K. and Tadesse, A., 2012b. Response of barley to liming of acid soils collected from different land use systems of Western Oromia, Ethiopia. Journal of Biodiversity and Environmental Sciences, 2 (7), pp. 1-13.

[16] Chude, V. O., Jayeoba, O. J. and Oyebanyi, O. O. 2005. Hand book on soil acidity and use of agricultural lime in crop production. Published by NSPFS Nigeria. Pp 7-24. 
[17] Cottenie, A. 1980. Soil and plant testing as a basis of fertilizer recommendations. FAO soil bulletin 38/2. Food and Agriculture Organization of the United Nations, Rome.

[18] Curtin, D. C., Campbell, A., Jalil, A. 1998. Effects of acidity on mineralization: $\mathrm{pH}$-dependence of organic matter mineralization in weakly acidic soils. Soil Biol. Biochem. 30, 57-64.

[19] Dawit, S, Fritzsche, F, Tekalign, Mammo, Lehmann, J, Zech, W. 2002. Phosphorus forms and dynamics as influenced by land use changes in the sub-humid Ethiopian highlands. Geoderma 105: 21-48.

[20] Daryl, D., Buchholz. 1983. Soil test interpretations and recommendations handbook Revised 5/2004 University of Missouri - College of Agriculture Division of Plant Sciences.

[21] Dereje, G., Tamene, D. and Anbesa, B., 2019. Effect of Lime and Phosphorus Fertilizer on Acid Soil Properties and Sorghum Grain Yield and Yield Components at Assosa in Western Ethiopia. World, 6 (2), pp. 167-175.

[22] Dikinya, O. and Mufwanzala, N. 2010. Chicken manureenhanced soil fertility and productivity: Effects of application rates. Journal of soil science and environmental management vol. 1 (3), pp. 46-54.

[23] Edmeades, D. C., Ridley, A. M. 2003. Using lime to ameliorate top soil and sub soil acidity. In: Rengel, Z. (ed.), Hand book of Soil Acidity. Marcel Dekker, Inc., New York, Basel. pp. 297-336.

[24] Fageria, N. K. and Nascente, A. S., 2014. Management of soil acidity of South American soils for sustainable crop production. In Advances in agronomy (Vol. 128, pp. 221-275). Academic Press.

[25] FAO (Food and Agriculture Organization). 2006. Plant nutrition for food security: A guide for integrated nutrient management. FAO, Fertilizer and Plant Nutrition Bulletin 16, Rome.

[26] FAO (Food and Agriculture Organization). 2014. Guidelines for International soil classification system for naming soils and creating legends for soil maps, Update 2015. Food and Agriculture Organization of the United Nations Rome, 2015, Rome. 70p.

[27] Gee, G. W. and Bauder. 1986. Particle size analysis. In A. Klute, \& A. Klute (Ed.), Methods of soil analysis part 1 (2 ed., pp. 383-412). Madison, Wisconsin: Soil sciince of America.

[28] Gopinath, KA., Supradip, S., Harit Pande, MS., Kundu, S., Gupta, HS. 2008. Influence of organic amendments on growth, yield and quality of wheat and on soil properties during transition to organic production. Nutr Cycl. Agroecosyst 82: $51-60$.

[29] Hazelton, P. and B. Murphy. 2007. Interpreting soil test results: What do all the numbers mean? 2nd Edition. CSIRO Publishing. 152p.

[30] Ivarson, KC. 1977. Changes in decomposition rate, microbial population and carbohydrate content of an acid peat bog after liming and reclamation. Canad. J. Soil Sci. 57, 129-137.

[31] Jones, C. A. 1983. Effect of soil texture on critical bulk densities for root growth. Soil Science Society of America Journal 47, 1028-1211.
[32] Kamprath EJ. 1984b. Crop response to lime on soils in the tropics, Agronomy and soil Science Society of America, Madison Wisconsin, USA In: Adams F. (Ed). Soil Acidity and Liming. $2^{\text {nd }}$ Edition. Agronomy Monograph 12. 1984b; 349368 .

[33] Kim, H. Tan. 2010. Principles of soil environmental chemistry. CRC press. New York.

[34] Kochian, L. V., Piñeros, M. A., Liu, J. and Magalhaes, J. V., 2015. Plant adaptation to acid soils: the molecular basis for crop aluminum resistance. Annual Review of Plant Biology, 66, pp. 571-598.

[35] Kotu, B. H., Verkuijl, H., Mwangi, W. M. and Tanner, D. G., 2000. Adoption of improved wheat technologies in Adaba and Dodola Woredas of the Bale Highlands, Ethiopia. CIMMYT.

[36] Ligeyo DO, Gudu SO. 2005. Further laboratory screening of More Kenya Maize Inbred lines for Tolerance to Aluminum In: Third year Progress Report, (March 2004 to 28 February 2005). Mcknight Foundation USA Project, EMBBRAPA, Purdue and Cornell University (USA) and Moi University (Kenya) Phase1, 2003-2005.

[37] Maheswarappa HP, Nanjappa HV and Hegde MR. 1999. Influence of organic manures on yield of arrow root, soil physico-chemical and biologicalproperties when grown as intercrop in coconut garden. Annals of Agricultural Research. 20: 318-323.

[38] Mamo, T. and Haque, I., 1987. Phosphorus status of some Ethiopian soils. Plant and Soil, 102 (2), pp. 261-266.

[39] Mamo, T. and Bekele, T., 1991. Soil, plant, water, fertilizer, animal manure and compost analysis. Working Document No. 13. International Livestock Research Center for Africa, Addis Ababa.

[40] McLean, E. O. 1965. Aluminum. Methods of Soil Analysis. Agron. In: C. A. Black (Ed.) No. 9. Part II. Am. Soc. Agron, pp. 978-998. Madison, Wisconsin. USA.

[41] Mittra B. N., Karmakar, S., Swain, D. K. and Ghosh, B. C. 2003. Fly Ash- a Potential Source of Soil Amendment and a Component of Integrated Plant Nutrient Supply System. 2003 International Ash Utilization Symposium, Centrefor Applied Energy Research, University of Kentucky, Paper no. 28.

[42] Moody PW, Aitken, R., and Dickson, T. 1998. Field amelioration of acid soils in south-east Queen land 111. Relationships of maize yield response to lime un-amended soil properties. Australian Journal of Agricultural Research. 1998; 49 (4): 649-656.

[43] Moradi, H., Fahramand, M., Sobhkhizi, A., Adibian, M., Noori, M., Abdollahi, S. and Rigi, K., 2014. Effect of vermicompost on plant growth and its relationship with soil properties. International Journal of Farming and Allied Sciences, 3 (3), pp. 333-338.

[44] Myers, J. A. 1988. Reductions in exchangeable Magnesium with liming acidic Ohio soils. Soil Sci. Soc. Am. J, 131-136.

[45] Naramabuye, F. X. and Haynes, R. J., 2006. Effect of organic amendments on soil $\mathrm{pH}$ and $\mathrm{Al}$ solubility and use of laboratory indices to predict their liming effect. Soil science, $171(10)$, pp. 754-763. 
[46] Nekesa, A. O. 2007. Effect of Minjingu phosphate rock and agricultural lime on maize, groundnut and soybean yields on acid soils of western Kenya. M. Phil Thesis, Moi University, Eldoret, Kenya.

[47] Olsen, S. R., Cole, C. V., Watanabe, F. S. and L. A. Dean, L. A. 1954. Estimation of available P in soil by extraction with sodium bicarbonate. Soil science, 96: 308-12.

[48] Rowell, D. L. 1994. Soil science: Methods \& Applications. Addison Wesley Longman Singapore Publishers (Pte) Ltd., England, UK. 350p.

[49] SAS (Statistical Analysis System) Institute. 2004. SAS/STAT user's guide. Proprietary software version 9.00. SAS Institute, Inc., Cary, NC.
[50] Sivaguru, M. and Horst, W. J. 1998. The distal part of the transition zones is the most aluminum-sensitive apical root zone of maize. Plant Physiology. 116, 155-163.

[51] Van Lierop, W. 1983. Lime requirement determination of acid organic soils using buffer Ph method. Can. Soil Sci. 63: 411423.

[52] Hailu. W. and Abay, A., 2013. Potential of local plants as NPK on small holder fields in southern Ethiopia: working paper 4 .

[53] Wildey, T. I. 2003. The influence of seed placed lime to reduce the acidifying effects of nitrogen fertilizers in direct seeding systems. M. S. thesis. Washington State Univ., Pullman. 